\title{
ANALISIS PENGARUH KOMPENSASI TERHADAP PRODUKTIVITAS KERJA KARYAWANCOCA-COLA INDONESIA
}

\author{
Lite \\ Email : $\underline{\text { lite@gmail.com }}$ \\ STIE Palangka Raya
}

\begin{abstract}
There is a universal awareness on the importance of productivity in improving national welfare. The productivity is an essential factor in maintaining and developing the success of an organization. So that a company can achieve its goals one of which to improve the work productivity, then it is an obligation for the leaders to provide motivation for the employees in the form of compensation.

This research is willing to achieve the goals namely (1) to determine the effects of salary, intensive, facility, position promotion and work environment on the work productivity of CocaCola Indonesia employees either simultaneously or partially (2) to determine the most influential factors on the work productivity of CocaCola Indonesia employees.

In this research, the population is all of the employees in production section CocaColaIndonesia. There are 130 employees as the research samples. The sample collection technique is bypurposivesampling technique. The data analysis tools used in this research are validity, reliability, classical assumption test, multiple regression, determination coefficient and hypothesis testing.

Results of the research are (1) There are effects of salary on the employee work productivity (2)There are effects of incentive on the employee work productivity (4) There are effects of work environment on the employee work productivity (5) There are significant effects of salary $\left(X_{1}\right)$, incentive $\left(X_{2}\right)$ allowances $\left(X_{3}\right)$, facility $\left(X_{4}\right)$, position promotion $\left(X_{5}\right)$ and work environment $\left(X_{6}\right)$ simultaneously on the work productivity $(Y)$. The salary has the dominant effects on the work productivity namely by $b 1=0,248$.
\end{abstract}

Keywords: Compensation, Employee Work Productivity 


\section{PENDAHULUAN}

Perkembangan industry yang semakin pesat di Indonesia kita menuntut para manajer perusahaan untuk ikut berperan aktif memajukan usahanya baik dibidang jasa maupun manufaktur. Upaya untuk melakukan hal tersebut dintaranya dengan cara meningkatkan produktivitas karyawan.

Peningkatan produktivitas ini harus diikuti pula dengan pemberian kompensasi yang layak bagi karyawan. Pentingnya arti produktivitas dalam meningkatkan kesejahteraan nasional telah disadari secara universal. Tidak ada jenis kegiatan manusia yang tidak mendapatkan keuntungan dari produktivitas, dimana produktivitas yang tinggi dapat ditingkatkan sebagai kekuatan untuk menghasilkan banyak barang-barang maupun jasa(Sinungan, 2007).

Agar tujuan perusahaan dalam meningkatkan produktivitas kerja dapat tercapai, maka sudah menjadi kewajiban pimpinan untuk memberikan motivasi pada karyawan dalam bentuk kompensasi. Kompensasi dapat berupa finansial misalnya upah, insentif, tunjangan, juga non finansial misalnya promosi jabatan dan lingkungan kerja (Rivai,2004).

Pemberian kompensasi yang layak dana dil merupakan bentuk balas jasa terhadap hasil kerja karyawan. Program kompensasi sangat penting bagi perusahaan karena mencerminkan upaya oganisasi untuk mempertahankan sumber daya manusianya.Bila program kompensasi yang didalamnya

mencakupsistempengupahan

tidakdiadministarsikan secara tepat,perusahaan

bisakehilanganparakaryawannyayang baikdan harusmengeluarkan biaya untukmenarik,menyeleksi,melatih dan mengembangkan penggantinya.

Selain upah, insentif juga merupakan bentuk kompensasi yang harus diberikan perusahaankepada 
karyawannya. Perhatian perusahaan dalam bentuk insentif dapat merangsang karyawan untuk lebih giat bekerja sehingga produktivitas kerja karyawan meningkat. Pemberian insentif lebih berorientasi pada hasil kerja, karyawan yang bekerja dengan hasil yang lebih baik akan mendapatkan insentif yang sesuai dengan pengorbanan yang telah dilakukan oleh karyawan. Pemberian insentif dimaksudkan untuk dapat meningkatkan produktivitas kerja dan mempertahankan karyawan yang berprestasi.

Selain kompensasi finansial, kompensasi nonfinansial berupa promosi jabatan yang diberikan perusahaan juga merupakan faktor yang mempengaruhi karyawan untuk lebih berprestasi dan loyal pada perusahaan. Karyawan akan merasa terpacu untuk memperoleh jabatan yang sesuai dengan bidangnya dan berupaya untuk meningkatkan kemampuan kerjanya. Promosi jabatan yang sesuai dengan jenjang karier dan bidang karyawan setia pada perusahaan yang pada gilirannya dapat meningkatkan produktivitasnya.

Kompensasi nonfinansial yanglainyaitulingkungankerja.Perhati an terhadap lingkungan kerja yang kondusif, nyaman dan menyenangkan merupakan bentuk kompensasi nonfinansial yang menjadi harapan karyawan. Karyawan akan merasa senang dan betah bekerja. Faktor-faktor yang mendukung kondisi fisik lingkungan kerja harus benar-benar diperhatikan oleh perusahaan agar karyawan tidak merasa jenuh dalam melakukan pekerjaannya. Lingkungan kerja yang bersih dan sehat memungkinkan karyawan dapat lebih berkonsentrasi dalam pekerjaannya dan secara tidak langsung karyawan akan mempertahankan atau bahkan meningkatkan produktivitas.

Obyek penelitian ini pada CocaCola Indonesia, yang merupakan 
sebuah perusahaan multinasional yang bergerak pembuatan minuman, sangat menarik untuk dipelajari karenasampai saatini masihtetapeksis walaupun banyak pesaing dan dalam menjalankan perusahaan senantiasa penuh ketidakpastian, terutama mengenai kejadian waktu yang akan datang, dalam hal ini adalah resiko yang mungkin terjadi. Oleh karena itu sudah selayaknya apabila peran manajemen sumberdaya manusia ditempatkan pada posisi yang strategis.

Tujuan dalam penelitian ini adalah untuk mengetahui pengaruh upah, insentif, tunjangan, fasilitas, promosi jabatan dan lingkungan kerja terhadap produktivitas kerja karyawan CocaCola Indonesia baik secara simultan maupun parsial.

\section{TINJAUAN PUSTAKA}

\section{Pengertianproduktivitas}

Produktivitas

kerja

mempunyai peranan yang penting dalam pencapaian tujuan organisasi atau perusahaan. Produktivitas kerja merupakan faktor penentu yang sangat berpengaruh untuk meningkatkan dan mengembangkan usaha. Suatu organisasi yang ingin meningkatkan daya tahannya sehingga meningkatkan kemampuannya untuk tumbuh dan berkembang, maka harus sungguhsungguhmemperhatikanfaktorprodu ktivitas.

Produktivitas kerja adalah kemampun memperoleh manfaat yang sebesar-besarnya dari sarana dan prasara yang tersedia dengan menghasilkan keluaran/output, bahkan kalau mungkin yang maksimal (Siagian,1995).

Menurut

Muchdarsah Sinungan (2005) produktivitas kerja merupakan hasil kerja yang dicapai seseorang baikdari kualitas maupun kuantitas, ketepatan waktu serta target yang telah ditetapkan oleh perusahaan. Berdasarkan beberapa definisi, dapat disimpulkan bahwa produktivitas kerja merupakan hasil yang dicapai oleh seseorang 
persatuan waktu baik dari segi (Martoyo: 2011). Kompensasi adalah kuantitas maupun kualitasnya.

\section{Kompensasi}

\section{a. PengertianKompensasi}

Kompensasi merupakan

sesuatu yang diterima karyawan sebagai pengganti kontribusi jasa karyawan pada perusahaan.

Pemberian kompensasi merupakan salah satu pelaksanaan fungsi manajemen sumberdaya manusia yang berhubungan dengan semua jenis pemberian penghargaan individual sebagai pertukaran dalam melakukan tugas keorganisasian (Rivai,2004). Istilah kompensasi mengandung cakupan yang lebih luas dari pada sekedar pemberian upah dan gaji, konsep upah dan gaji lebih menekankan pada balas jasa yang bersifat financial maupun nonfinansial. Kompensasi adalah pegaturan keseluruhan pemberian balas jasa bagi “employers"maupun"employees"bai $\mathrm{k}$ yang langsung berupa uang(finansial) maupun yang tidak langsung berupa uang(nonfinansial) segala sesuatu yang diterima para karyawan sebagai balas jasa dari kerja karyawan pada perusahaan. Pemberian kompensasi merupakan suatu masalah yang kompleks dan paling berarti bagi karyawan maupun organisasi.(Handoko,2001). Salah satu cara manajemen untuk meningkatkan prestasi kerja,motivasi, kepuasan kerja dan produktivitas kerja karyawan adalah kompensasi.

Kompensasi merupakan balas jasa yang diberikan perusahaan kepada karyawan atas jasanya pada perusahaan. (Umar,2003). Sedangkan menurut Umi Sukamti Kompensasi adalah Uang dan jaminan yang diberikan kepada pegawai sebagai penukar dari kerja mereka. Dari beberapa pendapat di atas dapat ditarik kesimpulan bahwa kompensasi adalah segala sesuatu yang diterima para karyawan baik berupa financial maupun non financial sebagai balas jasa untuk kerja mereka.

\section{b. Jenis-jenis Kompensasi}


Menurut Gary Dessler (2006) diberikan kepada karyawan selain macam bentuk pembayaran yang berupa gaji, juga berupa kompensasi karyawan adalah tunjangan dan fasilitas.

(1)Pembayaran secara langsung 4. Hipotesis

(directfinancialpayment), yaitu

Hipotesis dalam penelitian ini pembayaran dalam bentuk uang yang adalah (a) Ada pengaruh antara dilaksanakan secara langsung, upah, insentif, tunjangan, fasilitas, sebagai suatu imbalan kepada promosi jabatan, dan lingkungan karyawan yang mencurahkan kerja terhadap produktivitas kerja tenaganya untuk perusahaan. karyawan bagian produksi (b)Tidak Pembayaran secara langsung dapat ada pengaruh antara upah, insentif, berupa gaji, komisi, dan bonus (2) tunjangan, fasilitas, promosi jabatan Pembayaran tidak langsung dan lingkungan kerja terhadap (indirectpayment), yaitu : suatu produktivitas kerja karyawan bagian pembayaran yang tidak langsung produksi. diberikan kepada karyawan yang Produktivitas yang telah memberikan tenaganya untuk dipengaruhi oleh enam variabel perusahaan biasanya berupa yaitu upah, insentif, fasilitas, tunjangan dan fasilitas.

Berdasarkan pengertian tunjangan, promosi jabatan dan lingkungan kerja, secara kompensasi yang telah dikemukaan matemamatik dapat ditulis sebagai di atas, bahwa kompensasi yang berikut:

$$
Y=f\left(X_{1}, X_{2}, X_{3}, X_{4}, X_{5}, X_{6}\right)
$$

\section{METODEPENELITIAN}

Dalam penelitian ini jenis penelitian sampel sebab peneliti penelitian yang digunakan adalah hanya akan meneliti sebagian dari penelitian sampel dikatakan populasi (Arikunto,2012). 
Dalam penelitian ini yang mejadi populasi adalah jumlah keseluruhan karyawan bagian produksi pada Coca Cola Indonesia yang berjumlah 382 orang.

Sampel dalam penelitian ini adalah seluruh karyawan tetap bagian produksi yang berjumlah 130 karyawan. Maksud dari penentuan sampel secara purposive adalah untuk memperoleh homogenitas responden.

\section{Variabel Penelitian}

Variabel-varibel dalam penelitian ini adalah (a) Varibel bebas (X) yaitu Variabel bebas adalah variabel yang mempengaruhi terhadap suatu gejala. Yang menjadi variabel bebas adalah kompensasi. Kompensasi merupakan sesuatu yang diterima karyawan sebagai pengganti kontribusi jasa karyawan pada perusahaan. Kompensasi dinilai dengan sub variabel dan indicator (1) Kompensasi finansial terdiri dari Upah (X1), Insentif (X2), Tunjangan (X3), Fasilitas (X4) (2) Kompensasi nonfinansial terdiri dari Promosi jabatan (X5), Lingkungan kerja (X6).

Yang menjadi Variabel terikat adalah variabel yang dipengaruhi suatu gejala. Variabel terikat dalam penelitian ini adalah produktivitas kerja karyawan. Produktivitas dalam penelitian ini diukur dari persepsi responden tentang kualitas, kuantitas hasil kerja, penerapan penghargaan dan sangsi bagi karyawan, dalam bekerja saya tidakpernah/menerima sangsi dari perusahaan dan karir karyawan didasarkan pada keahlian dan prestasi kerja.

Analisis kuantitatif yang dilakukan dengan regresi linier berganda, dengan alat bantu skala likert dengan skor (Singarimbun dan Effendi, 2010). Jawaban sangat setuju $=5$, setuju=4, ragu-ragu=3, tidak setuju=2 dan sangat tidak setuju=1.

Sebelum melakukan analisis data maka data diuji sesuai asumsi klasik.

Analisis regresi berganda digunakan untuk meramalkan 
seberapa besar pengaruh upah, produktivitas kerja, dengan rumus insentif, tunjangan, fasilitas, promosi (Sudjana,2001).

jabtan, lingkungan kerja dan

$$
\mathrm{Y}=\mathrm{b} 0+\mathrm{b} 1 \mathrm{X} 1+\mathrm{b} 2 \mathrm{X} 2+\mathrm{b} 3 \mathrm{X} 3+\mathrm{b} 4 \mathrm{X} 4+\mathrm{b} 5 \times 5+\mathrm{b} 6 \times 6 \ldots+\mathrm{bnXn}
$$

Keterangan:

$\mathrm{Y}=$ Produktivitas kerja

$\mathrm{b} 0=$ Konstanta

$\mathrm{b} 1=$ Koefisienregresi $\mathrm{X} 1$

$\mathrm{b} 2=$ Koefisienregresi $\mathrm{X} 2$

$\mathrm{b} 3=$ KoefisienregresiX3

$\mathrm{b} 4=$ Koefisienregresi $\mathrm{X} 4$

b5 = KoefisienregresiX5

b6 = KoefisienregresiX6

$\mathrm{X} 1=\mathrm{Upah}$

$\mathrm{X} 2=$ Insentif

$\mathrm{X} 3=$ Tunjangan

$\mathrm{X} 4=$ Fasilitas

$\mathrm{X} 5=$ Promosi Jabatan

X6 = Lingkungan Kerja

\section{HASIL PENELITIAN}

Berdasarkan hasil penelitian dari masing-masing hasil nilai tdapat diketahui bahwa secara sendiri hitung dan nilai F- hitung yang maupun secara bersama-sama memiliki nilai signifikansi lebih kecil terdapat pengaruh upah, Insentif, dari 0,05.

tunjangan dan fasilitas, promosi

Upah (X1) perhitungan regresi jabatan dan lingkungan kerja menunjukkan bahwa upah terhadap produktivitas kerja memberikan pengaruh positif dan karyawan CocaCola Indonesia signifikan terhadap produktivitas Central Java, hal ini dapat diketahui kerja karyawan Coca Cola Indonesia. 
Hal ini sejalan dengan Heidjrachman R (2000) upah adalah suatu penerimaan sebagai suatu imbalan dari pemberian jasa yang telah dilakukan berfungsi sebagai jaminan kelangsungan atau dinilai dalam bentuk uang yang ditetapkan menurut suatu persetujuan undangundang dan peraturan yang dibayarkan atas perjanjian kerja antara pemberi kerja dan penerima kerja yang bertujuan untuk meningkatkan produktivitas kerja. Hal ini mengindikasikan pemberian upah yang diberikan Coca Cola Indonesia berupa upah yang diberikan sesuai keadilan, upah sesuai dengan pengorbanan, upah sesuai masakerja,upah sesuai dengan kebutuhan dan upah yang diberikan sesuai dengan aturan pemerintah sangat berarti bagi karyawan untuk memberi daya tarik kepada karyawan dengan pembayaran yang sesuai dan adil sehingga lebih giat bekerja karena adanya upah yang tinggi maka produktivitas kerja karyawan akan meningkat.
Insentif (X2) hasil perhitungan regresi menunjukkan bahwa Insentif memberikan pengaruh positif dan signifikan terhadap produktivitas kerja karyawan. Hal ini sejalan dengan penelitian Gary Dessler(1996) Program insentif disesuaikan dengan memberikan bayaran tambahan berdasarkan produktivitas, penjualan, keuntungan, atau upaya pemangkasan biaya.

Tujuan utama program insentif adalah untuk mendorong dan mengimbali produktivitas karyawan dan efektivitas biaya. Hal ini mengindikasikan insentif yang ada di Coca Cola Indonesia sangat berpengaruh pada produktivitas kerja karyawan. Hal ini mengindikasikan karyawan Coca Cola Indonesia penyelesaian tugas sesuai yang ditentukan oleh perusahaan, insentif yang diterima sesuai standar kelayakan, Insentif yang diberikan mendorong untuk lebih giat bekerja, insentif yang 
diterima dapat memenuhi kebutuhan secara minimal dan insentif yang diberikan mengandung unsure keadilan. Kondisi yang demikian akan menciptakan iklim kerja yang baik bagi karyawan sehingga produktivitas akan meningkat.

Tunjangan (X3) Dari hasil perhitungan regresi menunjukkan bahwa tunjangan memberikan pengaruh positif dan signifikan terhadap produktivitas kerja karyawan. Hal ini sejalan dengan penelitian Ranupandojo (2004) pada umumnya setiap perusahaan mempunyai suatu kebijakan paket tunjangan, dengan maksud untuk mendorong para karyawan untuk berprestasi sehingga akan meningkatkan produktivitas kerja. Hal ini mengindikasikan tunjangan merupakan faktor yang dipertimbangkan untuk signifikan terhadap produktivitas meningkatkan produktivitas kerja kerja karyawan. Hal ini sejalan karyawan dalam bekerja Coca Cola dengan penelitian Moenir (1990) yang Indonesia dengan tunjangan hari dimaksud dengan fasilitas ialah raya yang diberikan sesuai dengan kebijakan pemerintah, tunjangan bayaran suplemen yang dibayarkan sesuai standar kelayakan, tunjangan uang makan dan transportasi, tunjangan perlengkapan kerja yang diterima memotivasi untuk lebih giat bekerja,dan tunjangan hari tua diterima dari perusahaan sesuai standar kelayakanya itu kebutuhan hidup minimal (KHM). Kebutuhan hidup minimal diartikan sebagai kebutuhan dasar untuk seorang pekerja agar dapat mempertahankan kondisi fisik dan mental untuk menjalankan tugas sebagai pekerja. Sehingga diharapkan tunjangan minimal merupakan jarring pengaman yang melindungi kepentingan pekerja.

Fasilitas (X4) hasil perhitungan regresi menunjukkan bahwa fasilitas memberikan pengaruh positif dan segalasesuatuyang 
digunakan,dipakai, ditempati dan Nitisemito (1991) promosi jabatan dinikmati oleh pegawai baik dalam adalah proses kegiatan pemindahan hubungan langsung dengan karyawan dari satu jabatan kepada pekerjaan maupun untuk kelancaran jabatan lain yang lebih tinggi. pekerjaan sehingga dapat Dengan demikian promosi akan meningkatkan produktivitas atau selalu diikuti oleh tugas, prestasi kerja.

tanggungjawab dan wewenang yang Hal ini mengindikasikan lebih tinggi dari jabatan yang fasilitas, merupakan faktor yang diduduki sebelumnya. Hal ini dipertimbangkan untuk mengindikasikan promosi jabatan meningkatkan produktivitas kerja merupakan faktor yang karyawan di Coca Cola Indonesia. dipertimbangkan untuk Fasilitas yang disediakan perusahaan meningkatkan produktivitas kerja penyediaan tempat ibadah, karyawan Coca Cola penyediaan kantin bagi karyawan, Indonesia.promosijabatansesuai fasilitas keamanan, fasilitas dengan kebutuhan, promosi jabatan pengobatan sangat lengkap dan sesuai dengan senioritas berdasarkan sesuai standar kesehatan dan fasilitas lama waktu bekerja, promosi jabatan alat perlidungan diri (APD) sehingga sesuai dengan keahlian dan produktivitas kerja akan meningkat. kesempatan yang sama diantara Promosi Jabatan (X5) hasil karyawan, promosi karyawan akan perhitungan regresi menunjukkan termotivasi untuk mengembangkan bahwa promosi jabatan memberikan diri dan promosi menimbulkan pengaruh sebesar positif dan pengalaman dan pengetahuan baru signifikan terhadap produktivitas serta daya dorong bagi karyawan. kerja karyawan. Hal ini sejalan Lingkungankerja (X6) Dari dengan penelitian Alex $S$ hasil perhitungan regresi 
menunjukkan bahwa lingkungan kerja memberikan pengaruh sebesar positif dan signifikan terhadap produktivitas kerja karyawan. Hal ini sejalan dengan penelitian Alex S.Nitisemito (1991) lingkungan kerja yang bersih, nyaman dan menyenangkan dapat menambah karyawan menjadi betah bekerja dan produktif. Lingkungan kerja merupakan betuk kompensasi non finansial yang dapat menunjang semangat kerja karyawan. Dalam meningkatkan produktivitas kerja karyawan, lingkungan kerja turut menentukan, artinya bila lingkungan kerja baik, teratur sesuai dengan ketentuan-ketentuan yang berlaku maka diharapkan dapat meningkatkan produktivitas kerja karyawan. Hal ini mengindikasikan fasilitas penerangan yang cukup, kondisi kebersihan, sarana sirkulasi udara untuk penyegar ruangan, perasaan aman danperusahaan telahmenata lingkunganyangkondusif
Produktivitas kerja karyawan (Y) Produktivitas kerja karyawan adalah suatu pendekatan interdisipliner untuk menentukan tujuan yang efektif, pembuatan rencana, aplikasi penggunaan cara yang produktifitas untuk menggunakan sumber-sumber secara efisien, dan tetap menjaga adanya kualitas yang tinggi. Produktivitas kerja karyawan Coca Cola Indonesia mengikutsertakan pendayagunaan secara terpadu sumberdaya karyawan dan ketrampilan, manajemen, informasi, energi dan sumber-sumber lain menuju kepada pengembangan dan peningkatan standar hidup

Produktivitas kerja karyawan Coca Cola Indonesia sangat meningkat, indikator yang digunakan adalah kualitas hasil kerja, kuantitas hasil kerja, penerapan penghargaan dan sangsi bagi karyawan,sangsi dari perusahaan, karir karyawan 
didasarkan pada keahlian dan persetujuan undang-undang dan prestasi kerja

peraturan yang dibayarkan atas

Upah (X1), Insentif (X2), perjanjian kerja antara pemberi tunjangan(X3) dan fasilitas, promosi jabatan dan lingkungan kerja (X4) secara bersama-sama berpengaruh terhadap produktivitas kerja karyawan (Y) Coca Cola Indonesia,hal ini dikarenakan produktivitas kerja akan meningkat apabila semakin baik upah, Insentif, tunjangan, fasilitas, promosi jabatan dan lingkungan kerja maka akan semakin tinggi produktivitas kerja karyawan.

\section{KESIMPULAN}

1. Terdapat pengaruh upah terhadap produktivitas kerja karyawan Coca Cola Indonesia. Hal ini sejalan dengan (HeidjrachmanR,2000) upah adalah suatu penerimaan sebagai suatu imbalan dari pemberian jasa yang telah dilakukan berfungsi sebagai jaminan kelangsungan atau dinilai dalam bentuk uang yang ditetapkan menurut suatu kerja dan penerima kerja yang bertujuan untuk meningkatkan produktivitas kerja.

2. Terdapat pengaruh antara insentif terhadap produktivitas kerja karyawan Coca Cola Indonesia. Hal ini sejalan dengan penelitian (Gary Dessler,2006) Program insentif disesuaikan dengan memberikan bayaran tambahan berdasarkan produktivitas, penjualan, keuntungan, atau upaya pemangkasan biaya. Tujuan utama program insentif adalah untuk mendorong dan mengimbali produktivitas karyawan dan efektivitas biaya.

3.Terdapat pengaruh antara tunjangan terhadap produktivitas kerja karyawan CocaCola Indonesia. Hal ini sejalan dengan penelitian (Ranupandojo,2004) pada umumnya setiap perusahaan 
mempunyai suatu kebijakan paket tunjangan, dengan maksud untuk mendorong para karyawan untuk berprestasi sehingga akanmeningkatkanproduktivitas kerja

4. Terdapat pengaruh antara fasilitas, promosi jabatan dan lingkungan kerja terhadap produktivitas kerja karyawan CocaCola Indonesia. Hal ini sejalan dengan penelitian Moenir (1990) yang dimaksud dengan fasilitas ialah segala sesuatu yang digunakan, dipakai, ditempati dan dinikmati oleh pegawai baik dalam hubungan langsung dengan pekerjaan maupun untuk kelancaran pekerjaan sehingga dapat meningkatkan produktivitas atau prestasi kerja

5. Terdapat pengaruh antara promosi jabatan terhadap produktivitas kerja karyawan CocaCola Indonesia.Hal ini sejalan dengan penelitian Nitisemito,(1991) promosi jabatan adalah proses kegiatan pemindahan karyawan dari satu jabatan kepada jabatan lain yang lebih tinggi. Dengan demikian promosi akan selalu diikuti oleh tugas, tanggungjawab dan wewenang yang lebih tinggi dari jabatanyang diduduki sebelumnya. Dan pada umumnya promosi juga diikuti dengan peningkatan income serta fasilitas yang lain. Tapi promosi itu sendiri sebenarnya mempunyai nilai, karenapromosi adalah merupakan bukti pengakuan antara lain terhadap prestasi kerja dan produktivitas kerja

6. Terdapat pengaruh antara lingkungan kerja terhadap produktivitas kerja karyawan CocaCola Indonesia . Hal ini sejalan dengan penelitian Nitisemito (1991) lingkungan kerja yang bersih, nyaman dan menyenangkan dapat menambah karyawan menjadi betah bekerja dan produktif. Lingkungan kerja merupakan bentuk 
kompensasinon financial yang dapat menunjang semangat kerja karyawan. Dalam meningkatkan produktivitas kerja karyawan, lingkungan kerja

turutmenentukan, artinyabila lingkungan kerja baik, teratur sesuai dengan ketentuanketentuan yang berlaku makadiharapkandapatmeningkatk anproduktivitas kerjakaryawan

7. Terdapat pengaruh signifikan antara upah, insentif, tunjangan, fasilitas, promosi jabatan dan lingkungan kerja secara bersamasama terhadap produktivitas kerja (Y). Nilai koefisien determinasi

\section{DAFTAR PUSTAKA}

Algifari. 2007.Statistik Induktif. Penerbit UPPAMP YKPN, Yogyakarta

Anoraga,Panji.2007. Manajemn Bisnis. Penerbit Rineka cipta, Jakarta

As'ad, Mohammad. 2001. Psikologi Industri. PenerbitLiberty, Yogyakarta.
(AdjustedRSquare) adalah sebesar 0,875 yang berarti variasi perubahan produktivitas kerja karyawan dipengaruhi oleh upah, Insentif, tunjangan dan fasilitas, promosi jabatan dan lingkungan kerja sebesar 87,5\%, sedangkan sisanya dipengaruhi oleh faktor lain yang tidak diteliti. Faktor yang paling berpengaruh terhadap produktivitas kerja karyawan CocaCola Indonesia adalah variabel yaitu upah hal ini ditujunjukkan nilai $\mathrm{b} 1=0,247$.

Ariknto, Suharsimi. 2012. Prosedur Penelitian. Penerbit Rineka Cipta, Jakarta

Effendy, Sofyan. Dan Singarimbun, Masri. 1997. Metode Penelitian Survei. PenerbitLP3ES, Jakarta

Ghozali, Imam. 2002. Aplikasi AnalisisMultivariate dengan Program SPSS. Badan Penerbit Universitas Diponegoro, Semarang 
Handoko,Hani,T.2001.Manajemen

Personalian DanSumberDaya

Manusia. BPFE Yogyakarta

Heidjraman, R. 2000.

Manajemen Personalia.

Penerbit

BPFE,

Yogyakarta

Marzuki.2000. Metodologi Riset.

Universitas Gajah Mada, Yogyakarta

Nitisemito,Alex.S.1991. Manajemen

Personalia. Yudhistira Yogyakarta

Nurgiyantoro, Burhan. 2000. Statistik

Terapan. Gajah mada university

Press, Yogyakarta.

Rivai,Veithzal.2004.ManajemenSumber

DayaManusiaUntukPerusahaan,

Penerbit RajaGrafindoPersada, Jakarta.

Kanisius

Siagian,Sondang.P.2001.Manaje men Bank Dana. Penerbit Bumi Aksara, Jakarta

Sudjana.2001.Statistik Untuk Ekonomi dan Niaga. penerbit Tarsito, Jakarta
Umar,Husein.2003.Riset Sumberdaya

Manusia Dalam Organisasi.

Penerbit Gramedia Pustaka

Utama, Jakarta 